\title{
Pengaruh Penambahan Inhibitor Ekstrak Kopi Dan Waktu Perendaman Terhadap Laju Korosi Pada Baja Karbon AISI 1020 Dalam Larutan NaCl $3 \%$
}

\author{
Hartono Simanjuntak ${ }^{(\mathrm{a})^{*}}$, Ediman Ginting $^{(\mathrm{b})}$, Suprihatin $^{(\mathrm{c})}$ \\ Jurusan Fisika FMIPA Unila, \\ Jl. Sumantri Brojonegoro 1, Bandar Lampung 35144. \\ ${ }^{(a)}$ hartonosimanjuntak67@gmail.com*, ${ }^{(b)}$ ediman.gintingsuka@fmipa.unila.ac.id, \\ ${ }^{(c)}$ suprihatin_itb@yahoo.com
}

Diterima (30 Mei 2019), Direvisi (04 Agustus 2019)

\begin{abstract}
Coffee extract used as an inhibitor in carbon steel samples AISI 1020, soaked in $3 \% \mathrm{NaCl}$ corrosive medium. By varying the immersion time by 4 days and 8 days, as well as the inhibitor concentrations of $0 \%, 3 \%, 5 \%$ and $7 \%$. After the treatment of the sample, the results of the calculation of the corrosion rate were the slowest in the sample AISI 10208.7 and the fastest in the sample AISI 1020 4.0. The inhibitor used has the highest efficiency value in the sample AISI 1020 4.7. The XRD characterization results showed that the crystal structure formed was pure Fe phase. SEM characterization shows the surface morphology of the sample, visible clumps in the sample. The characterization of EDS in the sample shows oxygen $(O)$ which indicates that the sample has been corroded.
\end{abstract}

Key words. AISI 1020, coffee extract, corrosion inhibitor, and $\mathrm{NaCl}$.

\begin{abstract}
Abstrak. Ekstrak kopi yang digunakan sebagai inhibitor pada sampel baja karbon AISI 1020, direndam dalam medium korosif $\mathrm{NaCl} 3 \%$. Dengan memvariasikan waktu perendaman 4 hari dan 8 hari, dan juga konsentrasi inhibitor $0 \%, 3 \%, 5 \%$ dan $7 \%$. Setelah perlakuan pada sampel diperoleh hasil perhitungan laju korosi yang paling lambat pada sampel AISI 10208.7 dan yang paling cepat pada sampel AISI 1020 4.0. Inhibitor yang digunakan mempunyai nilai efisiensi paling tinggi pada sampel AISI 1020 4.7. Hasil karakterisasi XRD menunjukkan bahwa struktur kristal yang terbentuk merupakan fasa $\mathrm{Fe}$ murni. Karakterisasi SEM menunjukkan morfologi permukaan sampel, terlihat gumpalan pada sampel. Karakterisasi EDS pada sampel terlihat unsur Oksigen (O) yang mengindikasikan bahwa sampel telah terkorosi.
\end{abstract}

Kata kunci. AISI 1020, ekstrak kopi, inhibitor korosi, dan $\mathrm{NaCl}$.

\section{PENDAHULUAN}

Baja atau besi banyak digunakan di masyarakat, mulai dari peralatan rumah tangga, sekolah, gedung, mobil, motor, dan lain-lain. Tidak hanya dalam masyarakat, penggunaan baja atau besi dalam suatu industri memegang peranan penting. Alat dan mesin serta instalasi dalam industri hampir $90 \%$ berasal dari bahan logam. Akan tetapi logam memiliki kelemahan yaitu mudah terkorosi, sehingga dapat mengakibatkan kegagalan produksi pada komponen industri [1].

Baja merupakan bahan logam yang mudah mengalami kerusakan dan kehilangan fungsi akibat proses alam, tetapi mempunyai popularitas tinggi karena logam ini mempunyai kemampuan untuk dipergunakan dalam berbagai macam kebutuhan, mudah dibuat, mudah dilas, dan harganya relatif murah [2].

Baja AISI 1020 adalah baja karbon rendah yang memiliki harga jual murah dibandingkan baja karbon sedang, baja karbon tinggi, dan baja paduan. Material ini digunakan sebagai bahan konstruksi umum, bahan poros (shaft), roda gigi (gear) dan lain-lain. Baja AISI 1020 mempunyai keuletan tinggi dan mudah dibentuk, tetapi kekerasannya rendah [3]. 
Pada umumnya baja karbon rendah sangat rentan terhadap korosi atau karat apabila berinteraksi dengan air laut. Korosi tidak dapat dihindari, namun laju korosi ini dapat dikurangi. Pengurangan laju korosi dapat dilakukan dengan proteksi katodik, proteksi anodik, pelapisan (coating), dan penambahan inhibitor. Inhibitor korosi terdiri dari inhibitor anorganik dan inhibitor organik. Inhibitor anorganik antara lain arsenat, kromat, silikat, dan fosfat yang merupakan jenis bahan kimia yang mahal, berbahaya, dan tidak ramah lingkungan, sehingga akan memberi efek buruk bila berinteraksi langsung dengan tubuh manusia. Oleh karena itu, saat ini sedang dikembangkan penggunaan bahan organik yang lebih alami untuk dijadikan bahan inhibitor korosi yang lebih aman dan biokompatibel dengan tubuh [4].

Korosi merupakan masalah yang serius dalam dunia material dan sangat merugikan karena dapat mengurangi kemampuan suatu kontruksi dalam memikul beban. Usia suatu kontruksi menjadi berkurang dari waktu yang sudah direncanakan. Tidak hanya itu apabila tidak diantisipasi lebih awal maka akan mengakibatkan kerugian-kerugian yang lebih besar antara lain bisa menimbulkan kebocoran, mengakibatkan berkurangnya ketangguhan, robohnya suatu kontruksi, meledaknya suatu pipa/bejana bertekanan dan mungkin juga dapat membuat pencemaran suatu produk [5]

Korosi atau pengkaratan dikenal sebagai peristiwa kerusakan logam karena adanya faktor metalurgi (pada material itu sendiri) dan reaksi kimia dengan lingkungannya yang menyebabkan terjadinya penurunan kualitas suatu bahan logam [6] .

Biasanya proses korosi logam berlangsung secara elektrokimia yang terjadi secara simultan pada daerah anoda dan katoda Bahan-bahan korosif (yang dapat menyebabkan korosi) terdiri atas asam dan garam, seperti asam klorida $(\mathrm{HCl})$ dan natrium klorida $(\mathrm{NaCl})$. Korosi tidak dapat dicegah tetapi lajunya dapat dikurangi. Berbagai cara telah dilakukan untuk mengurangi laju korosi, salah satunya dengan pemakaian inhibitor. Inhibitor korosi dapat didefinisikan sebagai suatu zat yang apabila ditambahkan dalam jumlah sedikit ke dalam lingkungan akan menurunkan serangan korosi lingkungan terhadap logam. Sejauh ini penggunaan inhibitor merupakan salah satu cara yang paling efektif untuk mencegah korosi, karena biayanya yang relatif murah dan prosesnya yang sederhana [7].

Inhibitor biasanya ditambahkan dalam jumlah sedikit, baik secara kontinu maupun periodik menurut suatu selang waktu tertentu.

Kopi mengandung kafein $\left(\mathrm{C}_{8} \mathrm{H}_{10} \mathrm{~N}_{4} \mathrm{O}_{2}\right)$, merupakan alkoloid yang mempunyai cincin purin dan merupakan derifat dari metil xanthine. Senyawa kafein dapat dijadikan inhibitor karena terdapat gugus nitrogen yang mengandung pasangan elektron bebas sebagai pendonor elektron terhadap besi untuk menbentuk senyawa kompleks. Inhibitor kafein merupakan inhibitor organik, sehingga proses penginhibisiannya disebabkan adsorbsi molekul dalam permukaan logam [8].

Kebanyakan inhibitor yang efisien yang digunakan dalam industri adalah senyawa-senyawa organik yang mengandung heteroatom seperti $\mathrm{O}, \mathrm{N}, \mathrm{S}$ dan ikatan rangkap di dalam molekulmolekulnya yang mefasilitasi adsorpsi pada permukaan logam [9]. Efisiensi inhibisi senyawa-senyawa organik adalah berkaitan dengan sifat-sifat adsorpsinya. Telah diketahui bahwa adsorpsi terutama bergantung pada adanya elektron-elektron $\Lambda$ dan heteroatom, yang menyebabkan adsorpsi molekul-molekul inhibitor pada permukaan logam lebih besar. Senyawasenyawa yang mengandung nitrogen $(\mathrm{N})$ dan belerang (S) adalah penting karena senyawa-senyawa ini sering memberikan inhibisi yang sangat baik dibandingkan dengan senyawa-senyawa yang hanya 
mengandung nitrogen atau belerang saja[10].

Pada penelitian kali ini, baja yang digunakan adalah baja karbon AISI 1020 yang direndam dalam medium korosif $\mathrm{NaCl}$ $3 \%$ pada konsentrasi inhibitor $0 \%, 3 \%, 5 \%$, dan $7 \%$ dengan waktu perendaman selama 4 hari dan 8 hari. Penelitian ini bertujuan untuk mengetahui pengaruh konsentrasi inhibitor ekstrak kopi dan waktu perendaman terhadap laju korosi pada baja karbon AISI 1020 dalam medium korosif $\mathrm{NaCl} 3 \%$ dan mengetahui efisiensi inhibisi dari ekstrak kopi pada baja karbon AISI 1020. Sampel baja hasil korosi dikarakterisasi dengan $X$-Ray Diffraction $(X R D)$ untuk melihat fasa pada baja, Scanning Electron Microscopy (SEM) dan Energy Dispersive Spectroscopy (EDS) untuk melihat produk korosi. Untuk menentukan laju korosi dilakukan menggunakan metode kehilangan berat.

\section{METODE PENELITIAN}

Penelitian ini dimulai dari pengambilan biji kopi sebanyak 1000 gram, lalu dikeringkan dalam mesin oven selama 2 jam pada suhu $150^{\circ} \mathrm{C}$ untuk menghilangkan kadar air. Biji kopi yang telah kering digiling hingga menjadi serbuk untuk memudahkan dan memaksimalkan proses ekstraksi. Bubuk kopi yang telah halus dimasukkan ke dalam botol yang berisi etanol untuk melakukan metode maserasi. Kemudian bubuk kopi direndam ke dalam pelarut selama 24 jam. Hasil perendaman disaring menggunakan kertas saring sehingga diperoleh filtrat. Filtrat kemudian diuapkan menggunakan mesin rotary evaporator dengan kecepatan $150 \mathrm{rpm}$ dan suhu $52^{\circ} \mathrm{C}$ hingga menghasilkan ekstrak pekat.

Selanjutnya baja yang sudah dipotong dengan ukuran $20 \mathrm{~mm}$, lebar $20 \mathrm{~mm}$, dan tinggi $5 \mathrm{~mm}$ dibersihkan dengan amplas dan ditimbang. Kemudian baja dilakukan uji OES (Optical Emission Spectroscopy) untuk mengetahui unsur-unsur yang terkandung pada baja tersebut. Setelah itu masuk dalam tahap pembuatan medium korosif $\mathrm{NaCl}$ dengan konsentrasi 3\%. Pembuatan larutan $\mathrm{NaCl}$ dengan konsentrasi $3 \%$ yaitu 3 gram $\mathrm{NaCl}$ ditambahkan dengan aquades sampai volume $100 \mathrm{ml}$. Setelah semuanya tersedia maka masuk dalam tahap perendaman. Pada tahap ini baja yang sudah ditimbang direndam dalam medium korosif $\mathrm{NaCl} 3 \%$ tanpa dan dengan inhibitor $3 \%, 5 \%$, dan $7 \%$, sehingga memakai 8 sample pengujian. Setelah direndam selama 4 hari dan 8 hari, maka ditimbang kembali dan dilakukan karakterisasi XRD, SEM-EDS dan perhitungan laju korosi dengan rumus:

$$
\mathrm{CR}=\frac{\mathrm{KW}}{\mathrm{AT} \rho}
$$

Dimana: $\mathrm{CR}=$ laju korosi ( $\mathrm{mm} /$ tahun), $\mathrm{K}=$ konstanta laju korosi, $\mathrm{W}=$ selisih massa (gram), $\mathrm{T}=$ waktu perendaman (jam), $\mathrm{A}=$ luas permukaan $\left(\mathrm{cm}^{2}\right), \rho=$ massa jenis $\left(\mathrm{gram} / \mathrm{cm}^{3}\right)$ [11].

\section{HASIL DAN PEMBAHASAN}

\section{Hasil Pengujian Komposisi}

Hasil analisis OES (Optical Emission Spectroscopy) pada baja AISI 1020 ditunjukkan pada tabel 1. 
Tabel 1. Komposisi unsur kimia penyusun baja.

\begin{tabular}{|c|c|c|}
\hline Elemen & $\begin{array}{c}\text { Kadar } \\
\text { Sampel } \\
(\%)\end{array}$ & Metode \\
\hline $\mathrm{C}$ & 0,139 & Spark-OES \\
\hline $\mathrm{Si}$ & 0,255 & $\begin{array}{l}\text { Spark-OES } \\
\text { Spectromaxx }\end{array}$ \\
\hline $\mathrm{Cr}$ & 0,116 & $\begin{array}{l}\text { Spark-OES } \\
\text { Spectromaxx }\end{array}$ \\
\hline $\mathrm{Al}$ & 0,0022 & $\begin{array}{l}\text { Spark-OES } \\
\text { Spectromaxx }\end{array}$ \\
\hline $\mathrm{Fe}$ & 98,9 & $\begin{array}{c}\text { Spark-OES } \\
\text { Spectromaxx }\end{array}$ \\
\hline
\end{tabular}

Hasil analisis OES pada Tabel 1 menunjukkan unsur besi (Fe) dengan kadar tertinggi sebesar 98,9\%. Untuk unsur karbon (C) pada sampel ini sebesar 0,139, sehingga dapat klasifikasikan bahwa sampel baja ini merupakan baja karbon rendah karena kandungan karbon (C) kurang dari $0,3 \%$. Sedangkan unsur paduan yang terdeteksi yaitu silika $(\mathrm{Si})$, kromium $(\mathrm{Cr})$ dan alumunium (Al), masing-masing sebesar $0,255 \% ; 0,116 \%$ dan $0,0022 \%$.

\section{Hasil Perhitungan Laju Korosi}

Hasil perhitungan laju korosi baja AISI 1020 dalam medium korosif $\mathrm{NaCl} 3 \%$ dengan laju korosi tertinggi dan terendah pada perendaman selama 4 hari dan 8 hari ditunjukkan pada Gambar 1.

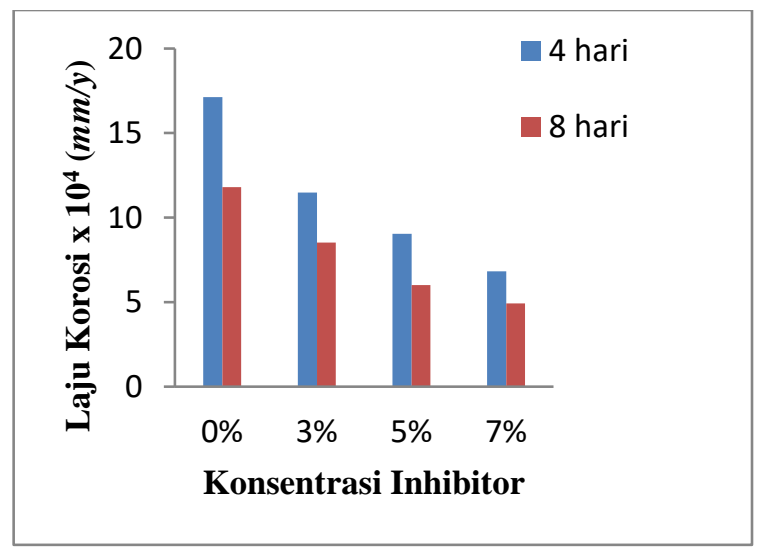

Gambar 1. Pengaruh konsentrasi inhibitor dalam medium korosif $\mathrm{NaCl} 3 \%$ terhadap laju korosi pada baja karbon AISI 1020.
Gambar 1. menunjukkan hubungan laju korosi dengan konsentrasi inhibitor ekstrak kopi pada medium korosif $\mathrm{NaCl}$. Pada perendaman 4 hari terlihat bahwa laju korosinya semakin menurun saat ditambahkan inhibitor, dan pada perendaman 8 hari terlihat bahwa laju korosinya menurun saat ditambahkan inhibitor.

Kemudian dilakukan perhitungan efisiensi inhibitor dengan rumus:

$\eta(\%)=\frac{\left(C R_{\text {uninhibited }}-C R_{\text {inhibited }}\right)}{C R_{\text {uninhibited }}} \times 100 \%$

Dimana: $\eta=$ Efisiensi inhibitor (\%), $\mathrm{CR}_{\text {unhibited }}=$ Laju korosi tanpa inhibitor (mm/tahun), $\mathrm{CR}_{\text {inhibited }}=$ Laju korosi dengan inhibitor (mm/tahun).

Selanjutnya grafik hubungan antara konsentrasi inhibitor dengan efisiensi ekstrak kopi disajikan dalam Gambar 2.

Berdasarkan Gambar 2 dapat dilihat bahwa efisiensi inhibitor terdapat pada konsentrasi $7 \%$ dengan waktu perendaman 4 hari yaitu sebesar $77,17 \%$. Hal ini karena pada waktu perendaman 4 hari senyawa kafein dalam ekstrak kopi membentuk lapisan tipis yang relatif banyak dan merata sehingga dapat menghalangi masuknya ionion korosif pada permukaan baja karbon AISI 1020. Sedangkan pada perendaman 8 hari, efisiensinya tidak terlalu besar karena semakin lama waktu perendaman akan mempengaruhi lapisan kafein yang melindungi permukaan baja sehingga semakin menipis. Menurut hasil penelitian [12] didapatkan waktu efisiensi perendaman yaitu selama 4 hari dimana penelitian ini menggunakan baja Schedule 40 grade B ERW dan menggunakan konsentrasi inhibitor ekstrak daun pepaya sebesar $15 \%$. 


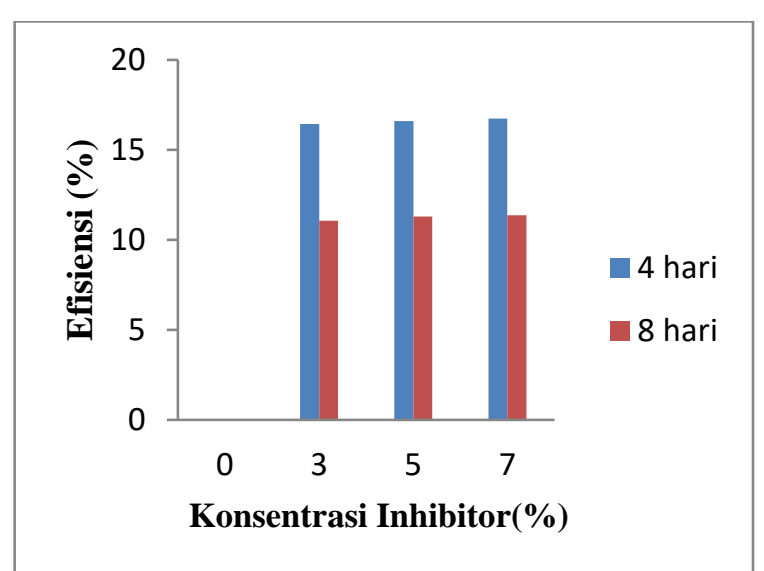

Gambar 2. Pengaruh konsentrasi inhibitor terhadap efisiensi inhibitor dalam medium korosif $\mathrm{NaCl} 3 \%$.

\section{Analisis XRD (X-Ray Diffraction)}

Karakterisasi menggunakan XRD dilakukan untuk mengetahui struktur kristal yang terbentuk pada AISI 1020. XRD menggunakan sinar-X sebagai penghantar untuk menganalisi sampel.Sinar- $X$ dengan panjang gelombang $(\lambda)$ diarahkan pada permukaan kristal dengan sudut $\theta$, kemudian sinar ini akan dihamburkan oleh bidang kristal. Karakterisasi dilakukan pada 4 sampel, yaitu: sampel baja PD Raw, PD 300.5, PD 700.5 dan PD 700.0 TP. Hasil analisis XRD disajikan pada Gambar 3.

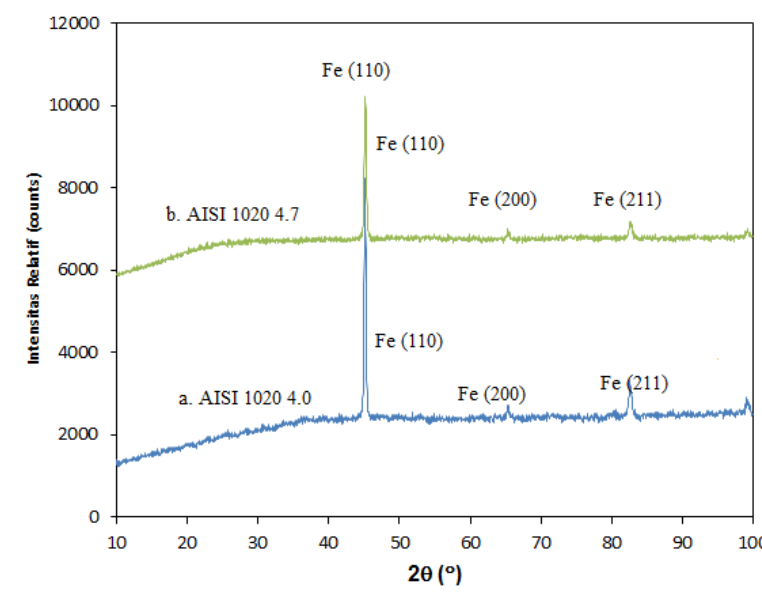

Gambar 3. Difraktogram hasil XRD pada baja dengan perendaman 4 hari a. AISI $10204.0 \%$; b. AISI $10204.7 \%$

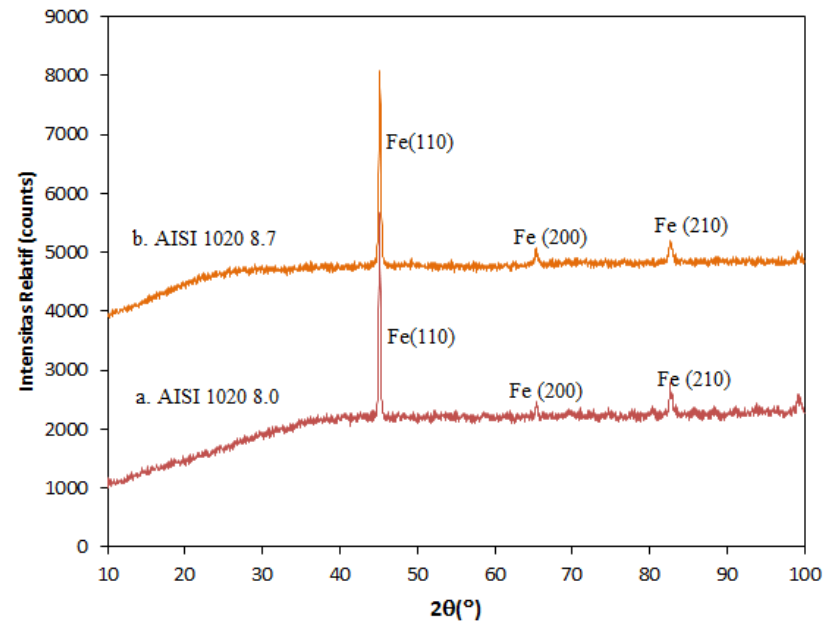

Gambar 4. Difragtogram hasil XRD pada baja dengan perendaman 8 hari a. AISI 1020 8.0; b. AISI 1020 8.7\%

\section{Analisis SEM-EDS}

Hasil analisis SEM pada keempat sampel yang memiliki laju korosi tertinggi dan terendah serta satu sampel merupakan baja raw AISI 1020 ditunjukkan pada

\section{Gambar 5 .}




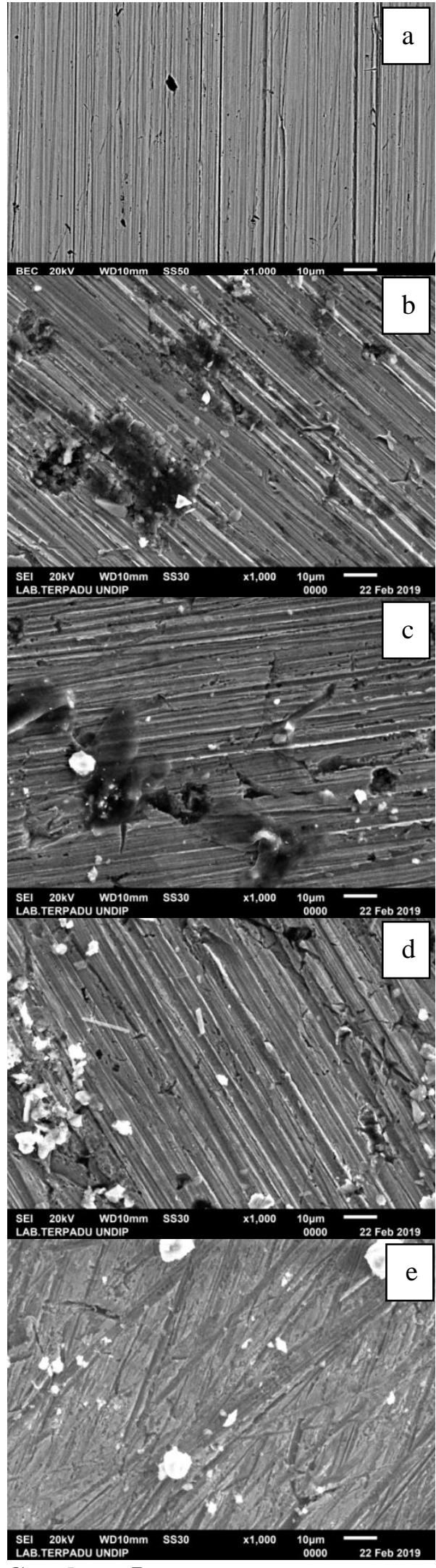

Gambar 5. Hasil SEM sampel baja raw AISI 1020 (a) lalu pada perendaman 4 hari dengan inhibitor $3 \%(b)$, dengan inhibitor $7 \%$ (c) dan pada perendaman 8 hari dengan inhibitor $3 \%$ (d), dengan inhibitor $7 \%$ (e).

Dari sampel yang telah diuji, pada sampel baja raw terlihat bahwa pada permukaan baja masih bersih dan hanya terlihat garis-garis yang merupakan sisa pengamplasan. Selain itu terlihat juga lubang-lubang kecil yang disebabkan oleh logam $\mathrm{Ni}$ yang dihasilkan saat peleburan, ini sesuai dengan penelitian Afriani dan Komalasari [12]. Lubang merupakan faktor utama penyebab terjadinya korosi pada suatu logam, karena merupakan jalan masuknya oksigen. Elektron-elektron yang terdapat pada logam akan bereaksi dengan oksigen, sehingga sampel akan kekurangan elektron dan terkorosi [13]. Kemudian pada perendaman selama 4 hari gumpalan yang terbentuk lebih sedikit dibandingkan dengan perendaman selama 8 hari. Selain itu, sampel yang direndam dengan penambahan inhibitor ekstrak kopi $7 \%$ gumpalan yang terbentuk lebih sedikit dibanding dengan sampel yang ditambahkan dengan inhibitor 3\%. Hal ini karena ekstrak kopi telah melapisi permukaan baja sehingga melindungi dari korosi yang terjadi.

Uji EDS dilakukan untuk melihat produk korosi yang tidak dapat dideteksi pada uji XRD. Hasil uji EDS pada sampel raw AISI 1020, sampel dengan laju korosi tertinggi dan sampel dengan laju korosi terendah ditunjukkan pada Gambar 6 dan Gambar 7. 


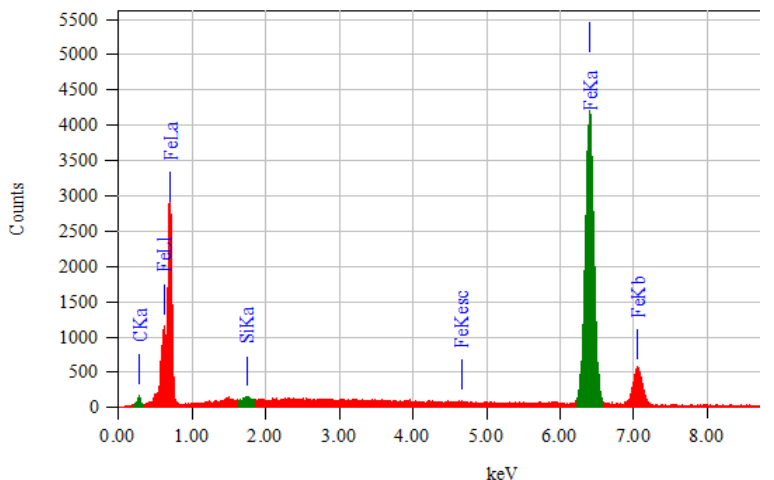

(a)

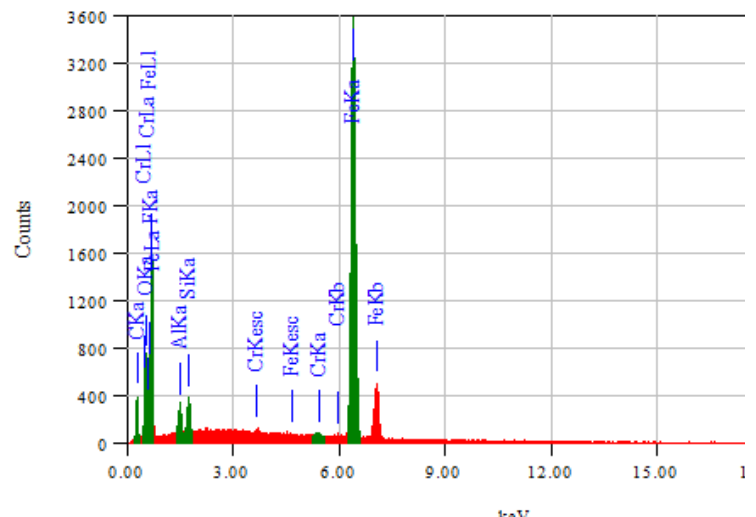

(b)

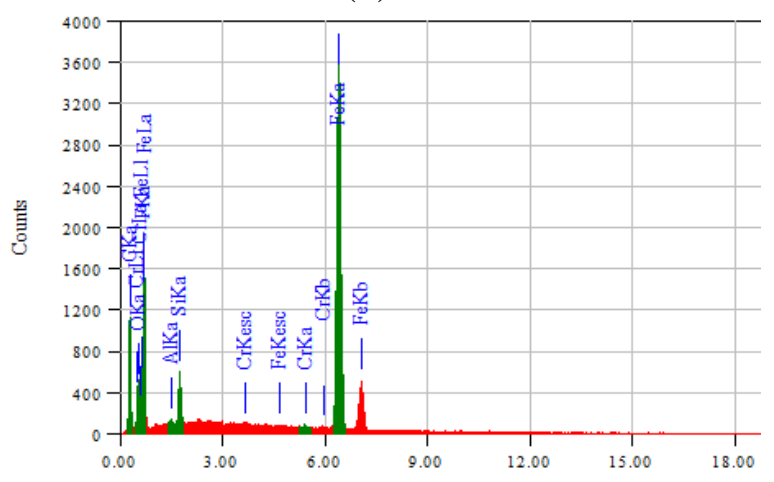

(c)

Gambar 6. Hasil EDS sampel baja raw AISI 1020 (a), sampel pada perendaman 4 hari dengan penambahan inhibitor $3 \%$ (b) dan dengan penambahan inhibitor $7 \%$ (c).

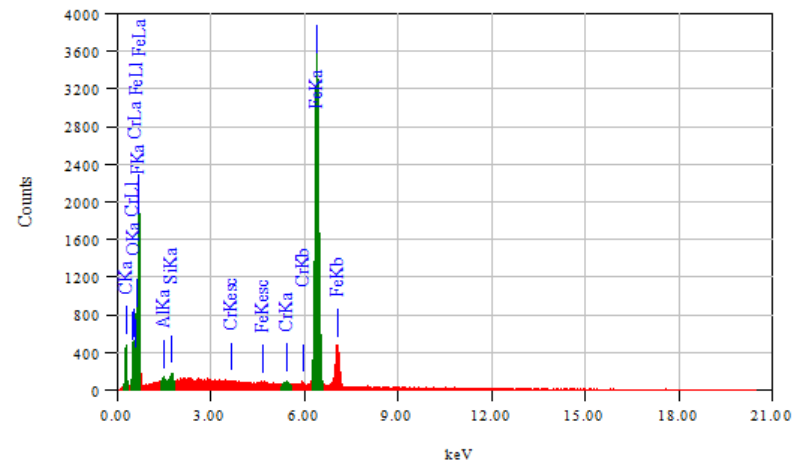

(a)

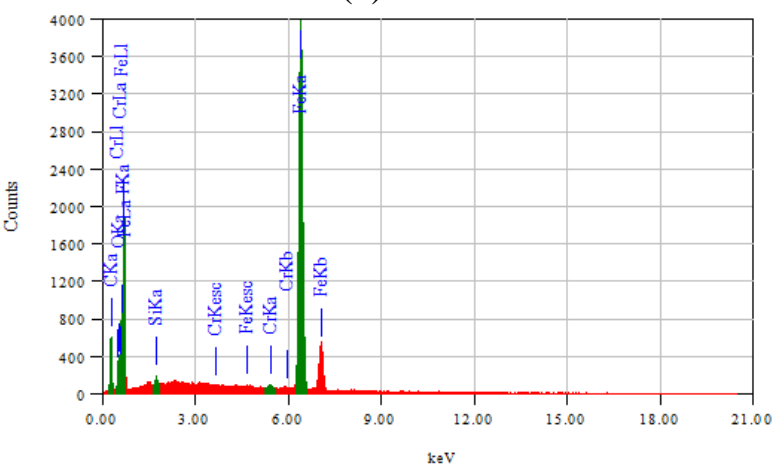

(b)

Gambar 7. Hasil EDS sampel pada perendaman 8 hari dengan penambahan inhibitor $3 \%$ (a) dan dengan penambahan inhibitor 7\% (b).

Sampel yang telah dilakukan perendaman dalam medium korosif $\mathrm{NaCl}$ $3 \%$ terdeteksi adanya unsur Oksigen (O), hal ini menandakan bahwa pada sampel tersebut telah mengalami korosi. Unsur Oksigen (O) pada sampel dengan penambahan ibhibitor 3\% lebih banyak dibandingkan dengan sampel dengan penambahan inhibitor $7 \%$. ini sesuai dengan penelitian Lukman dan Triwikantoro [14]. Pada perendaman 8 hari, sampel dengan penambahan inhibitor 3\% memiliki massa besi (Fe) lebih banyak dibandingkan dengan sampel dengan penambahan inhibitor $7 \%$. Hasil ini sesuai dengan penelitan Repangga [15]. Hal ini karena pada sampel yang telah ditambahkan inhibitor telah terlindungi dari korosi, sehingga unsur besi pada sampel tersebut tidak akan berkurang terlalu banyak. 


\section{KESIMPULAN}

1. Pada perendaman 4 hari laju korosi paling rendah terjadi pada konsentrasi inhibitor $7 \%$, dan pada perendaman 8 hari laju korosi paling rendah terjadi pada konsentrasi inhibitor $7 \%$.

2. Efisiensi maksimal dari inhibitor ekstrak kopi dalam medium korosif $\mathrm{NaCl} 3 \%$ terdapat pada konsentrasi $7 \%$ dengan waktu perendaman 4 hari yaitu sebesar $16,73 \%$.

3. Pada perendaman 4 hari dengan penambahan inhibitor 7\%, laju korosinya lebih besar dibandingkan dengan perendaman selama 8 hari dengan penambahan inhibitor $7 \%$ yaitu sebesar 6,82 mmpy dan 4,92 mmpy.

4. Karakterisasi XRD menunjukkan bahwa pada semua sampel terdeteksi tiga puncak yang merupakan fasa besi $(\mathrm{Fe})$ dengan bidang kisi yang sama yaitu 110 , 200 dan 211.

5. Karakterisasi SEM menunjukkan mikro struktur permukaan baja pada sampel AISI 4.7 dan AISI 8.7 lebih sedikit terbentuk produk korosi dari pada permukaan baja pada sampel AISI 4.3 dan AISI 8.3.

6. Karakterisasi EDS pada sampel AISI 4.3 dan AISI 8.3 menunjukkan bahwa kandungan unsur oksigen $(\mathrm{O})$ lebih besar dibandingkan pada sampel AISI 4.7 dan AISI 8.7, dimana pada sampel AISI 4.3 sebesar $19,57 \%$ dan sampel AISI8.3 sebesar $17,79 \%$. Sedangkan pada sampel AISI 4.7 sebesar $15,28 \%$ dan sampel aisi 8.7 sebesar $17,14 \%$.

\section{Ucapan Terimakasih}

Penulis mengucapkan terimakasih kepada pengurus Laboratorium Fisika Dasar, Fisika Inti, dan Kimia Organik FMIPA Universitas Lampung untuk fasilitas Laboratorium.

\section{DAFTAR PUSTAKA}

[1] A. Budianto, K. Purwantini, dan B. T. Sujitno, "Pengamatan Struktur Mikro pada Korosi Antar Butir dari Material Baja Tahan Karat Austenitik Setelah Mengalami Proses Pemanasan," JFN, vol. 3, no. 2, hal. 107-130, 2009.

[2] S. Handani dan M. S. Elta, "Pengaruh Inhibitor Ekstrak Daun Pepaya Terhadap Korosi Baja Karbon Schedule 40 Grade B ERW Dalam Medium Air Laut Dan Air Tawar," J.Ris.Kim, vol. 5, no. 2, hal. 175-179, 2012.

[3] R. S. Irianty dan Khairat, "Ekstrak Daun Pepaya Sebagai Inhibitor Korosi pada Baja AISI 4140 dalam Medium Air Laut," Teknobiologi, vol. 4, no. 2, hal. 77-82, 2013.

[4] P. A. Machfudzoh, M. N. Amin, dan L. S. D. Putri, "Efektivitas Ekstrak Daun Belimbing Wuluh sebagai Bahan Inhibitor Korosi pada Kawat Ortodonsi Berbahan Dasar NikelTitanium (Effectiveness of Bilimbi Leaves Extract as Corrosion Inhibitor on Nickel-Titanium Orthodontic Wire)," Artikel Ilmiah Hasil Penelitian Mahasiswa 2014, no. kelompok 3, 2014.

[5] W. Wibowo dan M. N. Ilman, "Studi Eksperimental Pengendalian Korosi pada Aluminium 2024-T3 di Lingkungan Air Laut Melalui Penambahan," Rekayasa Proses, vol. 5, no. 1, hal. 10-16, 2011.

[6] F. Nugroho, "Penggunaan Inhibitor untuk Meningkatkan Ketahanan Korosi pada Baja Karbon Rendah," Angkasa, vol. 7, no. 1, hal. 151-158, 2015.

[7] A. Wahyuningsih, Y. Sunarya, dan S. Aisyah, "Metenamina sebagai Inhibitor Korosi Baja Karbon dalam Lingkungan Sesuai Kondisi 
Pertambangan Minyak Bumi," Sains dan Teknol. Kim., vol. 1, no. 1, hal. 17-29, 2010.

[8] A. P. Yanuar, H. Pratikno, dan H. S. Titah, "Pengaruh Penambahan Inhibitor Alami terhadap Laju Korosi pada Material Pipa dalam Larutan Air Laut Buatan," Tek. ITS, vol. 5, no. 2, hal. 297-302, 2016.

[9] M. F. Sidiq, S. Hidayatulloh, dan Siswiyanti, "Analisa Pengaruh Inhibitor Ekstrak Rimpang Jahe terhadap Laju Korosi Internal Pipa Baja ST-41 pada Air Tanah," Simetris, vol. 8, no. 1, hal. 141-146, 2017.

[10] S. Utomo, "Pengaruh Konsentrasi Larutan NaNo2 sebagai Inhibitor terhadap Laju Korosi Besi dalam Media Air Laut," Teknologi, vol. 7, no. 2, hal. 93-103, 2017.

[11] B. Prameswari, "Studi Efektifitas Lapis Galvanis Terhadap Ketahanan
Korosi Pipa Baja Astm a53 Di Dalam Tanah ( Underground Pipe )," Tek. Kim., vol. 5, no. 2, hal. 175179, 2008.

[12] F. A. S, Komalasari, dan Zultiniar, "Proteksi Katodik Metoda Anoda Tumbal Untuk Mengendalikan Laju Korosi," Jom FTEKNIK, vol. 1, no. 2, hal. 1-12, 2014.

[13] V. L. . Vlack, Ilmu dan Teknologi Bahan (Ilmu Logam dan Bukan Logam). Elsevier B.V., 1994.

[14] Lukman dan Triwikantoro, "Pengaruh Unsur Korosif Pada Air Hujan," Semin. Nas. Pascasarj., hal. 4, 2009.

[15] R. Y. Aditama, E. Ginting, dan Syafriadi, "Efektivitas Ekstrak Daun Pepaya ( Carica Papaya L ) sebagai Inhibitor pada Baja Karbon AISI 1020 dalam Medium Korosif $\mathrm{NaCl} 3$ \%," Teor. dan Apl. Fis., vol. 07, no. 01, hal. 69-76, 2019. 
Simanjuntak, dkk: Pengaruh Penambahan Inhibitor Ekstrak Kopi Dan Waktu Perendaman Terhadap Laju Korosi Pada Baja Karbon Aisi 1020 Dalam Larutan Nacl 3\% 